\title{
Relation between mineral composition of human hair and common illnesses
}

\author{
MICHALAK Izabela ${ }^{*}$, CHOJNACKA Katarzyna \& SAEID Agnieszka \\ Institute of Inorganic Technology and Mineral Fertilizers, Wroctaw University of Technology, 25 Smoluchowskiego, Wroctaw 50-372, Poland
}

Received November 20, 2011; accepted March 16, 2012

\begin{abstract}
The aim of the present study was to find the relation between mineral composition of human hair and illnesses such as infections of the respiratory system, asthma, vertigo, migraine, nervousness, hair loss, dandruff, brittle fingernails and white spots on fingernails. The mineral content of human hair was determined by multielemental analysis using ICP-OES and ICP-MS. Information about the health condition of the examined subjects was obtained by questionnaire. It was found that the hair of individuals who currently suffered from infections of the respiratory system or who had asthma had higher Zr content, the hair of sufferers of vertigo had a lower $\mathrm{Ca}, \mathrm{La}$ and $\mathrm{Sr}$ content and in the hair of migraine sufferers the $\mathrm{W}$ content was higher than in the hair of healthy subjects. The level of $\mathrm{K}$ in the hair of nervous people was three times higher than in hair of people who never suffered from nervousness. Individuals who complained of hair loss had an increased level of $\mathrm{Cu}$ in the hair. For individuals with dandruff, brittle fingernails and white spots on fingernails, the content of $\mathrm{Ca}$ and $\mathrm{La}$ in the hair was higher than in the hair of individuals who did not suffer from any of these conditions. The results of this study indicate that the metal content in hair could be used in the diagnosis of some common illnesses.
\end{abstract}

hair, mineral composition, common illnesses, ICP-OES

Citation: Michalak I, Chojnacka K, Saeid A. Relation between mineral composition of human hair and common illnesses. Chin Sci Bull, 2012, 57: 3460-3465, doi: 10.1007/s11434-012-5385-7

Over the last 20-30 years, considerable effort has been directed at the measurement of trace metal levels in various human tissues (e.g. human hair) to find correlations between the trace metals and human health and diseases [1]. Recently, hair has become the focus of attention because of its unique potential to reveal retrospective information about the nutritional status and the exposure of individuals [2]. Many trace elements accumulate in hair at levels at least ten times higher than in blood serum or urine [3].

Several studies have examined the relations between the mineral composition of hair and human health. For example, Forte et al. [4] assessed the metal content of hair as a reliable marker of Parkinson's disease. They hypothesized that imbalances in the levels of metals in the body could be cofactors of risk for disease. Their findings suggested a probable relationship between the pathology of the disease and a

*Corresponding author (email: izabela.michalak@pwr.wroc.pl) deficiency of Fe in the hair of patients [4]. Lech [5] determined whether the content of selected bioelements and toxic metals in the hair would be useful in clinical diagnostic procedures in certain chronic neurological disorders related to the deficiency of essential elements or to an excess of toxic metals. The results of that study showed that the determination of some metals, especially $\mathrm{Mg}$ and $\mathrm{Pb}$, in hair was helpful in the diagnosis of diseases of the neurological system in children. Park et al. [6] investigated the possible relationship between minerals and metabolic syndrome by analyzing the mineral content of hair. They found that the content of $\mathrm{Ca}, \mathrm{Mg}$ and $\mathrm{Cu}$ in the metabolic syndrome group was significantly lower than in the control group, whereas the amount of $\mathrm{Na}, \mathrm{K}$ and $\mathrm{Hg}$ in the metabolic syndrome group was significantly higher than in the control group. MacPherson and Bacsó [7] evaluated the use of hair $\mathrm{Ca}$ content as a non-invasive diagnostic marker for atherosclerosis and, hence, as a predictor of risk of coronary heart 
disease. People living in high risk areas had lower hair $\mathrm{Ca}$ content (Scotland, $431 \mathrm{mg} \mathrm{kg}^{-1}$ ) than people in lower risk areas (South-west England, $532 \mathrm{mg} \mathrm{kg}^{-1}$ ). Chen et al. [8] found that the concentrations of $\mathrm{Cd}, \mathrm{Cu}, \mathrm{Na}$ and $\mathrm{K}$ in the hair of a boy with Gorham-Stout Syndrome were far higher than in the hair of healthy people. The concentration of $\mathrm{Cd}$ was two times that of the reference while the concentrations of $\mathrm{Cr}$ and $\mathrm{Zn}$ were insufficient for health. The ratio of $\mathrm{K} / \mathrm{Na}$ was also higher than that of the healthy group.

It is also important to emphasize that some controversy exists about the use of hair samples as an indicator of environmental exposure, health status or disease state. It is argued that before hair analysis can be considered a valid tool for the assessment of exposure to or the health impact of a particular substance, more research is needed to establish standardized reference ranges, to gain a better understanding of biological variations in hair growth with age, gender, race and ethnicity, to understand the pharmacokinetics and to further explore dose-response relationships [9]. The results obtained in this study were related to previously established reference values for elements in the hair of Polish students [10].

In the present work, the mineral analysis of hair was undertaken in an attempt to find a relation between the mineral content of hair and commonly occurring diseases, such as infections of the respiratory system, asthma, vertigo, migraines, nervousness, hair loss, dandruff, brittle fingernails, and white spots on fingernails.

\section{Materials and method}

\subsection{Sampling and preparation}

Hair samples were provided by volunteers, who previously filled in a questionnaire which included questions on their individual characteristics like sex, age, properties of hair, dietary habits, health condition (occurrence of infections of the respiratory system, asthma, vertigo, migraines, nervousness, hair loss, dandruff, brittle fingernails, and white spots on fingernails). The present study was carried out on hair sampled from 155 subjects (58 males and 97 females), average age $24 \pm 9$ years. The subjects all lived in Wrocław and its surroundings, meaning that the participants (students and employees of Wrocław University of Technology) were subjected to similar environmental and occupational exposure.

The participants cut hair $(5-\mathrm{cm}$ long) from the nape of the neck immediately after four consecutive washings of their hair with Johnson's Baby Shampoo [11] and drying (for cutting the hair, new surgical scissors made from stainless steel were used (Hilbro International (Pvt) Limited)). The shampoo was selected for its composition; the only metal cation present was Na. The hair was stored in a paper envelope and was digested without additional washing steps. The goal was to develop an easy analytical procedure that did not require extractions from hair using acids, organic solvents, etc. On the one hand, extraction methods are presented as the methods that remove exogenous contamination, while on the other, they are seen as a source of contamination.

\subsection{Analytical methods}

The content of 39 elements (Ag, Al, As, B, Ba, Bi, Ca, Cd, $\mathrm{Ce}, \mathrm{Co}, \mathrm{Cr}, \mathrm{Cu}, \mathrm{Fe}, \mathrm{Hg}, \mathrm{K}, \mathrm{La}, \mathrm{Li}, \mathrm{Mg}, \mathrm{Mn}, \mathrm{Mo}, \mathrm{Na}, \mathrm{Ni}, \mathrm{P}$, $\mathrm{Pb}, \mathrm{Pt}, \mathrm{Rb}, \mathrm{S}, \mathrm{Sb}, \mathrm{Se}, \mathrm{Si}, \mathrm{Sn}, \mathrm{Sr}, \mathrm{Ti}, \mathrm{Tl}, \mathrm{V}, \mathrm{W}, \mathrm{Y}, \mathrm{Zn}, \mathrm{Zr}$ ) in hair was determined by ICP-OES (macroelements) and ICP-MS (microelements and toxic elements), as described previously [12]. The As, Co, Cd, Cr, Mn, Ni, Pb and V content was analyzed by ICP-MS. Hg was determined by atomic absorption spectroscopy AMA-254 (Czech Republic). The remaining elements were detected by ICP-OES. The hair samples $(0.5 \mathrm{~g})$ were solubilized with $5 \mathrm{~mL}$ concentrated $(69 \% \mathrm{~m} / \mathrm{m})$ nitric acid (Suprapur grade, Merck) and digested in a microwave oven (Milestone Start D, USA). After mineralization, the samples were diluted with ultra pure water deionized by Aquadem $50 \mathrm{~L}$, Wilhelm Werner GmbH (Germany) and Millipore Simplicity UV (France) systems to $50 \mathrm{~g}$. The samples were then analyzed directly by ICP-OES Vista MPX (Australia) with pneumatic nebulizer for macroelement content and after ten-times dilution, by ICP-MS Thermo Scientific (Germany) for the content of microelements, toxic elements and other trace elements. All the analyses were repeated three times (the relative standard deviation of the measurement did not exceed $5 \%$ ). The presented data are the arithmetic mean from the three measurements. Uncertainty was also reported. For the preparation of standard solutions $\left(1.0,10,50,100 \mathrm{mg} \mathrm{L}^{-1}\right)$ the multielemental standard (100 mg L ${ }^{-1}$ Astasol®, Prague, Czech Republic) was used.

The analytical process was controlled by NCS Reference Material-Human Hair NCS ZC81002 from China National Analysis Center. The analyses were carried out in a laboratory certified by ILAC-MRA and by the Polish Centre of Accreditation (nr AB 696) according to ISO/IEC 17025.

\subsection{Statistical methods}

The results were elaborated statistically by STATISTICA version 9.0. The differences between the groups were investigated with one-way analysis of variance (ANOVA) using the Tukey multiple comparison range test. The results were considered to be significantly different at $P<0.05$.

\section{Results and discussion}

In the present paper, the relations between the content of some elements in hair and illnesses, declared in the questionnaire by the examined subjects, are discussed. Basing on a literature survey, it was hypothesized, that the concentra- 
tion of a substance in a hair sample could indicate exposure to that substance or a malfunction of absorption of the substance, and therefore the concentration may not indicate internal exposure or the source of exposure. For most substances, data are insufficient to predict health effects from the measurement of the substance in hair [9]. Here, an explanation was sought for the increased or decreased level of some elements in hair.

In this paper, only the statistically significant results (mean $\pm \mathrm{SD}$ ) are presented. It was found, that in the examined group of people, those that reported diseases of the respiratory system (frequent infections of the respiratory system or asthma) had increased level of $\mathrm{Zr}$ in their hair. The hair of the individuals currently suffering from infections of the respiratory system contained three times more $\mathrm{Zr}$ than the hair of healthy people and four times more in the hair of those suffering from asthma, (Table 1). $\mathrm{Zr}$ has been found to be present in dust, which can constitute the pathogenesis of asthma [13]. Petran et al. [14] reported that females employed in a pottery product factory were exposed to $\mathrm{Zr}$ pigments and sometimes developed $\mathrm{Zr}$ pneumoconiosis. A more common source of $\mathrm{Zr}$ is deodorants, which are commonly combined with antiperspirant agents, such as aluminum zirconium tetrachlorohydrex gly and aluminum zirconium trichlorohydrex gly. These two chemicals are the most frequent active ingredients in commercial antiperspirants [15]. It has been reported that $\mathrm{Mg}$ smoothes away the symptoms of asthma [13]. In this study, the individuals that currently suffered from asthma, had lower level of $\mathrm{Mg}$ in their hair $\left(70.5 \pm 25.8 \mathrm{mg} \mathrm{kg}^{-1}\right)$ than the group that did not suffer from this disease $\left(124 \pm 111 \mathrm{mg} \mathrm{kg}^{-1}\right)$; however, this difference was not statistically significant.

Vertigo is an inner ear disorder that is a common cause of dizziness. This disorder is believed to be caused by loose calcium carbonate crystals that move in the sensing tubes of the inner ear. American Academy of Neurology confirmed that people with osteoporosis, or low bone density, were reported to be three times more likely to have vertigo than individuals with normal bone density and people with osteopenia, the stage preceding osteoporosis, were two times more likely to have vertigo. These findings suggested that people with vertigo probably have a problem with $\mathrm{Ca}$ metabolism. In the present study, in hair of subjects presently suffering from vertigo, the Ca content was $12 \%$ lower than in subjects who did not suffer vertigo attacks. Reduced levels of $\mathrm{La}$ (by $8 \%$ ) and $\mathrm{Sr}$ (by $42 \%$ ) were also observed in the hair of subjects with vertigo (Table 2). The relatively low decrease in $\mathrm{Ca}$ content in hair may be because, in the questionnaire, only one person declared that she or he currently had osteoporosis, two said that they had osteoporosis in the past, two indicated that they currently had a broken limb, and 16 declared that they had broken bones in the past (small population).

Recent statistics suggest that $6 \%$ of men and $18 \%$ of women in the United States suffer from migraine and that those numbers are increasing [16]. In our questionnaire, five males reported suffering from migraine, three at present and two in the past, making them $9 \%$ of the male population. Of the females, 27 (14 at present and 13 in the past,) reported suffering migraines, making up $28 \%$ of the female population.

Table 1 The content of $\mathrm{Zr}$ in the hair $\left(\right.$ mean $\pm \mathrm{SD} ; \mathrm{mg} \mathrm{kg}^{-1}$ ) of people suffering from infections of the respiratory system and asthma

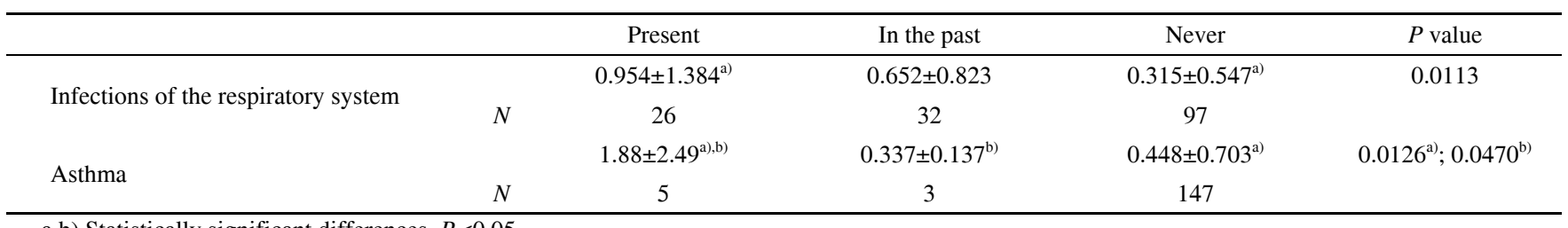

a,b) Statistically significant differences, $P<0.05$.

Table 2 The content of elements in the hair (mean $\left.\pm \mathrm{SD} ; \mathrm{mg} \mathrm{kg}^{-1}\right)$ of people suffering from vertigo, migraine, nervousness and hair loss

\begin{tabular}{|c|c|c|c|c|c|}
\hline & & Present & In the past & Never & $P$ value \\
\hline \multirow[t]{3}{*}{ Vertigo } & $\mathrm{Ca}$ & $2148 \pm 1367^{\mathrm{a})}$ & $3287 \pm 1956^{\text {a) }}$ & $2410 \pm 1168$ & 0.0433 \\
\hline & $\mathrm{La}$ & $0.538 \pm 0.372^{\mathrm{a})}$ & $0.827 \pm 0.409^{a)}$ & $0.579 \pm 0.304$ & 0.0496 \\
\hline & $N$ & 117 & 18 & 20 & \\
\hline \multirow[t]{2}{*}{ Migraine } & $\mathrm{W}$ & $3.65 \pm 2.60^{\mathrm{a})}$ & $2.57 \pm 2.12$ & $1.96 \pm 1.97^{\mathrm{a})}$ & 0.0442 \\
\hline & $N$ & 17 & 15 & 123 & \\
\hline \multirow[t]{2}{*}{ Nervousness } & $\mathrm{K}$ & $293 \pm 686^{\text {a) }}$ & $55.5 \pm 31.6$ & $93.5 \pm 133^{\mathrm{a})}$ & 0.0342 \\
\hline & $N$ & 54 & 15 & 86 & \\
\hline \multirow[t]{2}{*}{ Hair loss } & $\mathrm{Cu}$ & $22.3 \pm 26.0$ & $35.3 \pm 50.7^{\mathrm{a})}$ & $16.9 \pm 11.5^{\mathrm{a})}$ & 0.0363 \\
\hline & $N$ & 50 & 25 & 80 & \\
\hline
\end{tabular}

a) Statistically significant differences, $P<0.05$. 
It has been hypothesized that an imbalance of mineral stores in the body can lead to spasms of the blood vessels and many researchers have suggested that $\mathrm{Mg}$ might play an important role in migraine attacks. In humans, $\mathrm{Mg}$ plays a role in preventing blood vessel spasm, inhibiting blood clotting, and stabilizing cell membranes, all of which are involved in migraine development [17]. Recent evidence suggests that up to $50 \%$ of migraine patients have lowered levels of tissue $\mathrm{Mg}$ during an acute migraine attack [18]. Another study found that brain $\mathrm{Mg}$ concentrations were $19 \%$ lower in patients during migraine attack compared to in healthy controls [19]. In the present work, in subjects currently suffering from migraine, statistically significant differences were only seen in the $\mathrm{W}$ content of in hair. The $\mathrm{W}$ content was $86 \%$ higher than in subjects without this neurological syndrome (Table 2). In the questionnaire, 17 subjects declared migraine headaches at present, 15 in the past and 123 never. The content of $\mathrm{Mg}$ in the hair of these subpopulations was $138 \pm 123 \mathrm{mg} \mathrm{kg}^{-1}$ (current sufferers), 107 \pm $3 \mathrm{mg} \mathrm{kg}^{-1}$ (past sufferers), $123 \pm 112 \mathrm{mg} \mathrm{kg}^{-1}$ (never suffered). The differences, however, were not statistically significant.

The content of $\mathrm{K}$ (important in controlling the activity of the heart, muscles, nervous system and most cellular functions [20] and also influences the mood [21]) in the hair samples of "nervous" subjects was higher than the level of $\mathrm{K}$ in the "calm" control group (Table 2). The K/Co ratio 458 (current sufferers), 141 (never suffered), 79 (past sufferers) was also higher than in the controls. This ratio was influenced by low levels of $\mathrm{Co}$, which can cause changeable mood and excitement. Lech [5] noted that the $\mathrm{Mg} / \mathrm{Zn}$ and $\mathrm{Mg} / \mathrm{Pb}$ ratios were usually higher in a group of healthy children $(N=108)$ that they studied $(\mathrm{Mg} / \mathrm{Zn}: 0.26 ; \mathrm{Mg} / \mathrm{Pb}$ : 123) and lower among children suffering from neurological diseases $(N=153)(\mathrm{Mg} / \mathrm{Zn}: 0.19 ; \mathrm{Mg} / \mathrm{Pb}: 51.3)$. Conversely, the $\mathrm{Zn} / \mathrm{Cu}$ ratio in hair was higher in the group of children suffering from neurological diseases $(\mathrm{Zn} / \mathrm{Cu}$ : 18.6) compared to the ration in the healthy children $(\mathrm{Zn} / \mathrm{Cu}: 15.8)$. In our work, the ratios of $\mathrm{Mg} / \mathrm{Zn}, \mathrm{Mg} / \mathrm{Pb}$ and $\mathrm{Zn} / \mathrm{Cu}$ for the whole population $(N=155)$ were as follows: $0.48 ; 44.7$ and 11.7. When our population was divided into two groups: suffering $(N=54)$ and not suffering $(N=86)$ from nervousness, our results agreed well with those of Lech [5]. The ratios of $\mathrm{Mg} / \mathrm{Pb}$ and $\mathrm{Mg} / \mathrm{Zn}$ in healthy subjects were higher (47.4 and 0.54, respectively) than in the subjects suffering from nervousness ( $\mathrm{Mg} / \mathrm{Pb}$ : 44.9; $\mathrm{Mg} / \mathrm{Zn}: 0.43$ ). For the $\mathrm{Zn} / \mathrm{Cu}$ ratio, the opposite was the case; the ratio was higher in the hair of subjects suffering from nervousness (13.4) compared to in healthy subjects (10.9). Lech [5] speculated that the high toxicity of $\mathrm{Pb}$ together with $\mathrm{Mg}$ deficiency might be the cause of the observed disorders of the nervous system in the children.

Hair loss and dandruff are common problems faced by many people. To cure these problems it is important to first identify the cause. Hair loss can be caused by various fac- tors, including: hormonal changes, poor nutrition, certain diseases and medical treatments, hair treatments, unhygienic scalp conditions or scalp infections (including dandruff) [22]. In the present study, a statistically significant difference $(P=0.0363)$ was observed for the content of $\mathrm{Cu}$ in the hair of people who suffered from hair loss compared with in the group without this problem. The average content of $\mathrm{Cu}$ in the hair of individuals from the first group was two times higher than in people from the second group (Table 2). It has been suggested that hair loss is commonly associated with $\mathrm{Cu}$ toxicity and $\mathrm{Zn}$ deficiency [23]. When high levels of $\mathrm{Cu}$ are detected in hair, it may be indicative of minor reactions in the body such as oily skin, acne, pigmentation problems, brittle and thin nails and sagging skin [24]. Campbell [20] found that patients with high $\mathrm{Cu}$ levels in hair often have a variety of symptoms such as fatigue, nervousness, depression, irritability, muscle and joint pain, tiredness, behavior problems, learning disabilities and mental diseases.

Dandruff can be caused by fungal colonization (Malassezia), stress, oily scalp, the use of many styling products which contain chemicals, poor diet, and shampooing too often or too little. Hair of subjects suffering from dandruff may have higher level of $\mathrm{Zn}$, because a common ingredient in anti-dandruff shampoos, zinc pyrithione, could be deposited in the form of micro-fine crystals on the scalp [25]. However, in the group of people examined in this study, the content of $\mathrm{Zn}$ was similar in all subjects. Hair of subjects, who declared dandruff problems in the past contained $297 \pm$ $201 \mathrm{mg} \mathrm{kg}^{-1}$ of $\mathrm{Zn}$, for those who currently had dandruff it was $244 \pm 181 \mathrm{mg} \mathrm{kg}^{-1}$ and for those who never had dandruff $236 \pm 150 \mathrm{mg} \mathrm{kg}^{-1}$. There were, however, statistically significant differences in the levels of Ca and La. Hair of subjects, who have dandruff at present, had lower content of $\mathrm{Ca}$ and La in comparison with subjects without this problem (Table $3)$. There is no unequivocal explanation for this result. All that can be suggested is that problems with hair could be caused by a deficiency or an overabundance of certain minerals or nutrients. Some reports suggest that $\mathrm{Ca}$ and $\mathrm{Mg}$ imbalance may be involved. For example, $\mathrm{Ca}$ directly affects the absorption of Fe, $\mathrm{Zn}, \mathrm{K}$ and $\mathrm{Mg}$. The ideal hair $\mathrm{Ca} / \mathrm{Mg}$ ratio was established to be 7.10 . As the ratio increases above this value, a relative $\mathrm{Mg}$ deficiency begins to manifest itself. An individual with $\mathrm{Mg}$ deficiency would then have decreased $\mathrm{Ca}$ requirements [26]. In our population $(N=155)$ the $\mathrm{Ca} / \mathrm{Mg}$ ratio was 18.8 . A study by MacPherson and Bacsó [7] revealed a strong relationship between water hardness and hair $\mathrm{Ca}$ content (the harder the water the higher the hair Ca). Additionally, 33\% more males than females suffer from dandruff, maybe because men tend to sweat more. This leads to an oily scalp. In our work, 19 males and 15 females currently suffered from dandruff. Hair of females contained two times more Ca (2270 $\mathrm{mg} \mathrm{kg}^{-1}$ ) and three times more $\mathrm{Mg}\left(169 \mathrm{mg} \mathrm{kg}^{-1}\right)$ than hair of males (Ca: $1213 \mathrm{mg} \mathrm{kg}^{-1}$; $\mathrm{Mg}$ : $55.6 \mathrm{mg} \mathrm{kg}^{-1}$ ). The $\mathrm{Ca}$ and $\mathrm{Mg}$ imbalance was much higher for men $(\mathrm{Ca} / \mathrm{Mg} 21.8)$ than for 
Table 3 The content of $\mathrm{Ca}$ and $\mathrm{La}$ in the hair (mean $\pm \mathrm{SD} ; \mathrm{mg} \mathrm{kg}^{-1}$ ) of people suffering from dandruff, brittle fingernails and white spots on fingernails

\begin{tabular}{|c|c|c|c|c|c|}
\hline & & Present & In the past & Never & $P$ value \\
\hline \multirow[t]{3}{*}{ Dandruff } & $\mathrm{Ca}$ & $1679 \pm 985^{\text {a) }}$ & $2841 \pm 1538^{\mathrm{a})}$ & $2321 \pm 1496$ & 0.00203 \\
\hline & $\mathrm{La}$ & $0.424 \pm 0.290^{\mathrm{a})}$ & $0.730 \pm 0.375^{\text {a) }}$ & $0.566 \pm 0.386$ & 0.00159 \\
\hline & $N$ & 34 & 40 & 81 & \\
\hline \multirow[t]{3}{*}{ Brittle fingernails } & $\mathrm{Ca}$ & $2813 \pm 1754^{\text {a) }}$ & $2587 \pm 1430$ & $1992 \pm 1189^{\text {a) }}$ & 0.0105 \\
\hline & $\mathrm{La}$ & $0.740 \pm 0.391^{\mathrm{a})}$ & $0.641 \pm 0.366$ & $0.476 \pm 0.340^{\mathrm{a})}$ & 0.000681 \\
\hline & $N$ & 50 & 15 & 90 & \\
\hline \multirow[t]{3}{*}{ White spots on fingernails } & $\mathrm{Ca}$ & $2346 \pm 1131$ & $2927 \pm 1793^{\text {a) }}$ & $2023 \pm 1287^{\mathrm{a})}$ & 0.0108 \\
\hline & $\mathrm{La}$ & $0.615 \pm 0.362$ & $0.728 \pm 0.413^{\mathrm{a})}$ & $0.497 \pm 0.344^{\mathrm{a})}$ & 0.0122 \\
\hline & $N$ & 25 & 41 & 89 & \\
\hline
\end{tabular}

a) Statistically significant differences, $P<0.05$.

women $(\mathrm{Ca} / \mathrm{Mg}$ 13.4).

Subjects, who currently complained of having brittle fingernails, had increased levels of $\mathrm{Ca}$ and $\mathrm{La}$ in hair. For both these elements, statistically significant differences (for Ca, $P=0.0105$; for La, $P=0.000681$ ) were observed between the groups that reported brittle fingernails and the group that did not (Table 3). It is important to emphasize that an increased level of $\mathrm{Ca}$ could show signs similar to the deficiency of $\mathrm{Zn}$ [13].

For white spots on fingernails, statistically significant differences were found for $\mathrm{La}$ and $\mathrm{Ca}$, the same elements as for brittle fingernails. Hair of subjects, who reported this effect, contained $45 \%$ more $\mathrm{Ca}$ and $46 \%$ more $\mathrm{La}$ than the hair of subjects who did not report the white spots (Table 3). In the questionnaire, 13 subjects declared that they had brittle fingernails and white spots on fingernails at present; 61 subjects said that they did not have these problems at all.

It is often stressed in the literature, that interpretation of the obtained data is difficult because of the lack of reference values (RVs) [9]. This gap is gradually being filled. For example, Druyan et al. [27] obtained reference values for Americans, Park et al. [28] for Koreans, and Senofonte et al. [29] did the same for an Italian population. However, these values can differ because of the different analytical methods used. In this study, the results were compared with reference values that were prepared for Polish students [10]. According to these values, the content of the elements in hair for which statistically significant differences were observed in this work should stay within the following ranges: Ca 733-4047 mg kg ${ }^{-1}$, Cu 8.51-35.0 mg kg ${ }^{-1}, \mathrm{~K}_{2} 2.9-115$ $\mathrm{mg} \mathrm{kg}{ }^{-1}$, La $0.158-1.042 \mathrm{mg} \mathrm{kg}^{-1}$, Sr $1.05-9.46 \mathrm{mg} \mathrm{kg}^{-1}, \mathrm{Zr}$ $0.043-0.788 \mathrm{mg} \mathrm{kg}^{-1}$. Hair of subjects who reported suffering from infections of the respiratory system and asthma, contained higher levels of $\mathrm{Zr}\left(0.954 \pm 1.384\right.$ and $1.88 \pm 2.49 \mathrm{mg} \mathrm{kg}^{-1}$, respectively) than the $\mathrm{Zr} \mathrm{RV}$. Higher values were also observed for $\mathrm{Sr}$ in hair of subjects suffering from vertigo, for $\mathrm{K}$ in sufferers of nervousness and for $\mathrm{Cu}$ in those reporting hair loss.

Variations in the elemental composition of hair were ra- ther high. Many factors related to individual characteristics influence the level of elements in hair. Every individual lives in a different environment, has different dietary and lifestyle habits and consequently undergoes different levels of exposure. The clinical symptoms that are observed as illnesses frequently have different etiologies.

Human biomonitoring studies yield direct information about human exposure to the various elements; however, the lack of controlled conditions like those possible in laboratory experiments can result in many confounding conclusions. For this reason, human biomonitoring studies require large populations and the use of statistical methods in the elaboration of the results.

\section{Conclusions}

The results of this study suggest that the determination of some metals in hair could be of help in the diagnosis of many diseases. The information on the health states of the examined subjects was obtained from the questionnaire, without medical consultation. Our results indicate that subjects with increased levels of $\mathrm{Zr}$ in hair could be expected to suffer from infections of the respiratory system and asthma. Subjects complaining of vertigo could have lowered levels of $\mathrm{Ca}, \mathrm{La}$ and $\mathrm{Sr}$ and those complaining of migraine, an increased level of W. Hair of nervous people had an increased level of K. For subjects with dermatological problems, dandruff, brittle fingernails and white spots on fingernails, statistically significant differences were found in the content of $\mathrm{Ca}$ and $\mathrm{La}$ in hair of the examined population compared with in the control.

Mineral analysis of human hair can be considered as a tool for the prediction of many illnesses; however, appropriate reference values are still required. For the Polish population, reference values are being prepared and could be used in the future in medical diagnostics to assess the excess or deficiency of micro, macroelements and toxic metals in human hair. We hope that this laboratory study 
will encourage other authors to conduct further studies that may result in clinically useful results.

This work was supported by the Ministry of Science and Higher Education, Poland (N N204 019135) and by a Fellowship co-financed by the European Union within European Social Fund.

1 Klevay L M, Bistrian B R, Fleming C R, et al. Hair analysis in clinical and experimental medicine. Am J Clin Nutr, 1987, 46: 233-236

2 Sela H, Karpas Z, Zoriy M, et al. Biomonitoring of hair samples by laser ablation inductively coupled plasma mass spectrometry (LA-ICP-MS). Int J Mass Spectrom, 2007, 261: 199-207

3 Maugh T H. Hair: A diagnostic tool to complement blood serum and urine. Science, 1978, 202: 1271-1273

4 Forte G, Alimonti A, Violante N, et al. Calcium, copper, iron, magnesium, silicon and zinc content of hair in Parkinson's disease. J Trace Elem Med Biol, 2005, 19: 195-201

5 Lech T. Lead, copper, zinc, and magnesium content in hair of children and young people with some neurological diseases. Biol Trace Elem Res, 2002, 85: 111-126

6 Park S B, Choi S W, Nam A Y. Hair tissue mineral analysis and metabolic syndrome. Biol Trace Elem Res, 2009, 130: 218-228

7 MacPherson A, Bacsó J. Relationship of hair calcium concentration to incidence of coronary heart disease. Sci Total Environ, 2000, 255: $11-19$

8 Chen M, Cao X, Mayouma L, et al. Trace element characteristics of a Gorham-Stout syndrome sufferer. Chin Sci Bull, 2008, 53: 1388-1392

9 Harkins D K, Susten A S. Hair analysis: Exploring the state of the science. Environ Health Perspect, 2003, 111: 576-578

10 Chojnacka K, Zielińska A, Górecka H, et al. Reference values for hair minerals of Polish students. Environ Toxicol Pharmacol, 2010, 29: 314-319

11 Wang T, Fu J, Wang Y, et al. Use of scalp hair as indicator of human exposure to heavy metals in an electronic waste recycling area. Environ Pollut, 2009, 157: 2445-2451

12 Chojnacka K, Michalak I, Zielińska A, et al. Inter-relationship between elements in human hair: The effect of gender. Ecotox Environ Safe, 2010, 73: 2022-2028

13 Kabata-Pendias A, Pendias H. Biogeochemistry of Trace Elements.
Warsaw: Polish Scientific Publishers PWN, 1999

14 Petran M, Olinici L, Cocârlă A, et al. Zirconium pneumoconiosis (Zr). J Med Prew, 2001, 9: 32-34

15 Lukacs V A, Korting H C. Antiperspirants and deodorants-ingredients and evaluation. Derm Beruf Umwelt, 1989, 37: 53-57

16 Stewart W F, Lipton R B, Celentano D D, et al. Prevalence of migraine headache in the United States: Relation to age, income, race, and other sociodemographic factors. JAMA, 1992, 267: 64-69

17 McCarty M F. Magnesium taurate and fish oil for prevention of migraine. Med Hypotheses, 1996, 47: 461-466

18 Mauskop A, Altura B M. Role of magnesium in the pathogenesis and treatment of migraine. Clin Neurosci, 1998, 5: 24-27

19 Ramadan N M, Halvorson H, Vande-Linde A, et al. Low brain magnesium in migraine. Headache, 1989, 29: 590-593

20 Campbell J D. Lifestyle, minerals and health. Med Hypotheses, 2001, 57: 521-531

21 Watts D L. Trace elements and neuropsychological problems as reflected in tissue mineral analysis (TMA) patterns. J Orthomol Med, 1990, 5: 159-166

22 Panagotacos P, ed. The Complete Book of Hair Loss Answers: Your Comprehensive Guide to the Latest and Best Techniques. Santa Rosa: Elite Books, 2005

23 Champion R H, Burton J L, Ebling F G. Zinc Deficiency and Skin Changes. Textbook of Dermatology. 5th ed. Oxford: Blackwell Scientific, 1992

24 Tabrizian I. Nutritional Medicine: Fact and Fiction. 4th ed. Perth, Australia: NRS Pub, 2003

25 Draelos Z D, Kenneally D C, Hodges L T, et al. Comparison of hair quality and cosmetic acceptance following the use of two anti-dandruff shampoos. J Investig Dermatol Symp Proc, 2005, 10: 201-204

26 Watts D L. Mineral imbalance, endocrines and hair tissue mineral analysis. TEI Newslett, 1993, 6: 1-7

27 Druyan M E, Bass D, Puchyr R, et al. Determination of reference ranges for elements in human scalp hair. Biol Trace Elem Res, 1998, 62: $183-197$

28 Park H S, Shin K O, Kim J S. Assessment of reference values for hair minerals of Korean preschool children. Biol Trace Elem Res, 2007, 116: $119-130$

29 Senofonte O, Violante N, Caroli S. Assessment of reference values for elements in human hair of urban schoolboys. J Trace Elem Med Biol, 2000, 14: 6-13

Open Access This article is distributed under the terms of the Creative Commons Attribution License which permits any use, distribution, and reproduction in any medium, provided the original author(s) and source are credited. 